This is the author's final, peer-reviewed manuscript as accepted for publication. The publisher-formatted version may be available through the publisher's web site or your institution's library.

\title{
Using Housing Futures in Mortgage Research
}

Shuang Zhu $\cdot$ R. Kelley Pace $\cdot$ Walter A. Morales

\section{How to cite this manuscript}

If you make reference to this version of the manuscript, use the following information:

Zhu, S., Pace, R. K., \& Morales, W. A. (2014). Using Housing Futures in Mortgage Research. Retrieved from http://krex.ksu.edu

\section{Published Version Information}

Citation: Zhu, S., Pace, R. K., \& Morales, W. A. (2014). Using Housing Futures in Mortgage Research. Journal of Real Estate Finance and Economics, 48(1), 1-15.

Copyright: ( Springer Science+Business Media, LLC 2012

Digital Object Identifier (DOI):10.1007/s11146-012-9381-0

Publisher's Link: http://link.springer.com/article/10.1007/s11146-012-9381-0 


\title{
Using Housing Futures in Mortgage Research
}

\author{
Shuang Zhu \\ Assistant Professor of Finance \\ Department of Finance \\ Kansas State University \\ Manhattan, KS 66506 \\ shuangzhu@ksu.edu \\ and \\ R. Kelley Pace \\ LREC Endowed Chair of Real Estate \\ Department of Finance \\ E.J. Ourso College of Business Administration \\ Louisiana State University \\ Baton Rouge, LA 70803-6308 \\ kelley@spatial.us \\ and \\ Walter A. Morales III \\ Commonwealth Advisors LLC, Baton Rouge, LA 70801 \\ Tel: +1-225-3439342 \\ morales@lsu.edu
}

April 9, 2014 


\begin{abstract}
Expectations of housing prices play an important role in real estate research. Despite their importance, obtaining a reasonable proxy for such expectations is a challenge. The existing literature on mortgage research either does not include housing expectation proxies in empirical models, or uses "backwardlooking" proxies such as past housing appreciation or time series forecasts based on past housing appreciation.

This paper proposes to use the transaction prices of Case-Shiller housing futures as an alternative "forward-looking" proxy. As an example, we compare the performances of four different expectation proxies in explaining mortgage default behavior. The loan level analysis shows that the futures based expectation proxy outperforms other proxies by having the highest regression model fit and being the only proxy that shows a significant negative effect on mortgage default behavior, as theory suggests. Out of sample predictions also show that futures have better prediction accuracy than other proxies. In addition, the paper shows that futures contain additional information that is not present in the backward-looking proxies.
\end{abstract}




\section{Introduction}

Economic decisions often rely on expectations of variables in the future. This presents a difficulty when working with empirical data since most variables represent the outcomes of past decisions and therefore may imperfectly capture such expectations.

For example, the expected house price plays a role in individual default decision since this affects both the benefit and the cost of making mortgage payments through the perceived value of the property and the option to default in the future (Kau and Kim, 1994; Ambrose et al., 1997; Foote et al., 2008). While many researchers (e.g., Shiller, 2007) pay attention to the role of housing expectations in the current mortgage crisis, obtaining a reasonable proxy for expected housing appreciation is a challenge. ${ }^{1}$ The fundamental difficulty is that market expectations are typically not directly observable. Because of this difficulty, current empirical mortgage research either (1) does not include housing expectation proxies in empirical models (e.g., Demyanyk and Van Hemert, 2009), (2) uses past housing appreciation (e.g., Bajari et al., 2008), or (3) uses a time series forecast (e.g., Goetzmann et al., 2009) as the proxy.

This paper proposes a new proxy of housing expectations in mortgage models by using the information from the transaction prices of Case-Shiller housing futures. Since the contract prices of futures are based on market participants' beliefs concerning future housing prices, the transaction prices incorporate the market expectation of housing prices. ${ }^{2}$

This paper compares the performances of four different housing expectation proxies in explaining default behavior. The four proxies are futures, past year appreciation from the Case-Shiller house price index (CSI), past year appreciation from the Federal Housing Finance Agency house price index (FHFA), and time series forecasts. In addition, we investigate the additional information content of futures that is not contained in the past price based measures.

The results show that futures are a promising proxy for housing expectations. First, futures have the highest regression model fit among all four

\footnotetext{
${ }^{1}$ For simplicity, we use the term appreciation for both price increases or declines.

${ }^{2}$ Financial futures are viewed as the market expectation of underlying product price movements in the financial derivatives literature. For example, the Federal funds futures are widely used as the market expectations of future monetary policies (e.g., Krueger and Kuttner, 1996; Hanley and McNeil, 2007).
} 
measures. This indicates that futures might explain default behavior better than other measures. Second, only futures consistently show that higher housing expectations lower the default propensity, as theory suggests. Other measures either exhibit mixed signs or are statistically insignificant. Third, futures have better out of sample prediction accuracy than other proxies in terms of the area under the receiver operating characteristic curve (AUC) measure. Fourth, even after combining other proxies in the same regression, the coefficient estimates and standard errors of futures remain about the same as with only futures in the regressions. This reveals that futures contain information not captured by historical prices.

Finally, futures may play a more important role in upcoming real estate research as the newly launched RPX housing futures trading on CBOE Futures Exchange covers more cities than the futures based on the Case-Shiller index.

The rest of the paper proceeds as follows: Section 2 introduces the data and variables, Section 3 presents the empirical results, and Section 4 concludes.

\section{Data, Variables and Summary Statistics}

This section first describes data sources and sample selection in Section 2.1, then introduces variables and specifications in Section 2.2, and provides summary statistics in Section 2.3.

\subsection{Data}

The S\&P/Case-Shiller home price indices (CSI) and the contract prices of housing futures with CSI as the underlying asset are from Bloomberg at the metropolitan (MSA) level. Housing futures are traded on the Chicago Mercantile Exchange (CME). House price indices from the Federal Housing Finance Agency (FHFA) are downloaded from their website at the MSA level. The loan-level data comes from Blackbox Logic's BBx. ${ }^{3}$ BBx covers over 90 percent of US non-agency residential securitized deals. ${ }^{4} \mathrm{BBx}$ has

\footnotetext{
${ }^{3} \mathrm{BBx}$ data is similar to Loan Performance data. BBx data information is available at www.bbxlogic.com/data.htm.

${ }^{4}$ Since our data is from privately securitized loans, the results may apply only to this set of mortgages.
} 
detailed mortgage origination information and monthly updates of mortgage payment information. Unemployment data is from the Bureau of Labor Statistics at the MSAs level. National average 30 year fixed rate mortgage (FRM) interest rates are from Freddie Mac's national mortgage survey. The zip code level household median incomes are from the 2000 Census.

Our sample includes single family, first lien loans with a 30 year contract term in the ten MSAs with housing futures transactions. We include mortgages originated between May 2006, when housing futures started trading on CME ${ }^{5}$ to December 2007 and track the loan performances quarterly through December 2009. ${ }^{6}$ Mortgages are limited to those entering the dataset within three months of origination to control for survival bias. The number of loans included in this study is 213,693 , with default rate equal to $33.3 \%$ and prepayment rate equal to $17.8 \%$.

\section{$2.2 \quad$ Variables}

The event of interest is default, which is defined as the first 90 days delinquency. At each time period, the status of the loan could be in default, prepaid in full, or censored. ${ }^{7}$ If the loan is either in default or prepaid, all subsequent observations are dropped out of the sample. The number of loan-quarter observations is about 1.7 million.

Explanatory variables include housing expectations, loan/borrower characteristics, lagged unemployment rates, neighborhood median income and controls for prepayment risk. Loan characteristics include HPI updated current loan-to-value ratio (CLTV), a piggyback dummy for the contemporary second lien status, initial contract rate, a full documentation status dummy, various mortgage types dummies, an investor dummy, a purchase dummy, the original loan amount, loan age, and a prepayment penalty dummy. We also include the difference of national average rates for 30 year fixed rate mortgages (FRM) between the current time and at loan origination to control for the prepayment risk. Borrower characteristic includes the credit score (Fico). Lagged unemployment rate is intended to capture the local macroe-

\footnotetext{
${ }^{5}$ Although Case et al. (1993) have long been advocating a derivative market for housing in US, it was not until May 2006 that such a market was established.

${ }^{6}$ After 2007 , because of the mortgage crisis, very few newly originated loans were added into the dataset.

${ }^{7}$ Loan status other than default or prepaid is considered censored which includes uninformative censoring and current status.
} 
conomic condition. Neighborhood income is used to account for the wealth effect. The variable definitions appear in Table 1.

This study examines four measures of housing expectations. The futures proxies are inferred from the transaction prices of housing futures. The CME issues futures contracts each quarter in February, May, August, and November. Market participants include builders and developers, lenders, mortgage portfolio managers, mutual funds, other financial institutions, and individual investors. We first calculate the average transaction prices of futures in the trading month one year before the maturity date, then divide the number by lagged two months CSI, and minus one to get the quarterly expectations. ${ }^{8}$ Next we linearly interpolate the quarterly data to obtain the monthly expectations.

The previous year appreciation rates and the time series forecasts are considered the competing measures. These historical price based measures are often used as expectation proxies because various studies such as Case and Shiller (1989) have established that housing appreciation exhibits positive serial dependence. ${ }^{9}$ In another words, past price appreciation helps predict future appreciation and individuals may form their expectations based on recent past appreciation. Therefore, the second and third measures are the previous one year appreciation rates from the CSI and FHFA indices. We consider both CSI and FHFA indices since these have been widely used and also are not perfectly correlated.

The fourth measure is the one year forecasts from time series model based on CSI. We employed the autoregressive integrated moving average (ARIMA) model since this is the most commonly used time series model. Factors are included in the model to account for possible seasonal patterns in housing prices. We first select the lags of the model, then use a 20 year rolling time window to fit the data each month for each MSA area, then forecast. This approach is dynamic and allows the model to incorporate the new information for each time period. The selection criteria for the lags is to make all 44 (from May 2006 to December 2009) rolling window regressions converge for each MSA. Due to the unusual housing price movements in our sample time period, the time series regressions do not converge in many cases when using longer lags. Therefore, we use relatively short time period lags in our model.

\footnotetext{
${ }^{8}$ Lagged two months HPI is used since the release of CSI is lagged by two months and that represents the information available at the transaction time.

${ }^{9}$ However, the high transactions costs in real estate do not imply that the predictability leads to arbitrage opportunities.
} 
Eight MSAs use $\operatorname{ARIMA}(12,1,0)$ and two MSAs use $\operatorname{ARIMA}(6,1,0)$. We use a simple time series model since simple models often perform better in forecasting competitions (Makridakis et al., 1983).

\subsection{Summary Statistics}

Table 2 reports the summary statistics of forecasting errors for different housing expectation measures for the ten MSA areas. Forecasting errors are calculated as the difference of the ex ante expectation and the ex post realized one-year housing appreciation. We report various summary statistics for prediction accuracy: the mean absolute error (MAE), the root mean squared error (RMSE), and the minimum and the maximum error. Several patterns appear. First, the four different measures yield varying forecasting errors, and futures overall outperform other proxies in forecasting housing appreciation. In terms of both the MAE and the RMSE, futures yield the lowest prediction errors in seven out of the ten MSAs. For example, in Miami, the RMSE of futures forecasting error is $12.62 \%$, while the RMSEs are $19.09 \%$, $24.10 \%$ and $18.68 \%$ for the past CSI, the past FHFA, and the time series forecasts respectively. For the remaining three MSAs, futures perform similarly to the best measures in Boston and Las Vegas areas, and perform poorly only in Denver. Futures also yield the narrowest range of prediction errors in eight out of the ten MSAs. Second, forecasting errors of previous year appreciations from CSI and FHFA also show differences. The past CSI seem to point to more pessimistic expectations than the past FHFA indices in all ten MSA areas since both the minimum and the maximum errors from past CSI are lower than those from the past FHFA. The main reason for the difference of the two indices lies in the different composition of the underlying assets. FHFA includes only mortgages purchased by Fannie Mae or Freddie Mac, while CSI has a broader coverage of underlying properties. Other reasons are that FHFA uses both transaction and appraisal values while CSI uses only transaction prices, and the weight given to properties with longer intervals between transactions are also different (Leventis, 2008). Third, time series forecasts tend to under perform other measures in general. It shows the largest dispersion in terms of the range of forecasting errors in all MSAs. Time series forecast errors could be very large. For example, in San Francisco area, the forecasting errors have a wide range from $-62.23 \%$ to $36.40 \%$.

Table 3 reports the Pearson correlation coefficients between futures and other housing expectation proxies. The number in the parenthesis under the 
correlation coefficients is the p-value for the null hypothesis that the correlation coefficient is not different from zero. First, note that the correlation coefficients are relatively low with the highest number being slightly higher than 0.7. Using a one percent significance level, past year appreciations from CSI and FHFA each have three areas that are significantly positively correlated with housing futures expectations. Time series forecasts have five MSAs that show significant correlations (although in the Boston area, the correlation is negative). The results show that futures are not highly correlated with other proxies. Both Table 2 and 3 indicate that futures seem to be a quite different proxy from those measures that are extrapolated from past housing prices.

\section{Empirical Results}

This section introduces the estimation model in Section 3.1, investigates the performances of various proxies for housing expectations in explaining default in Section 3.2, compares out of sample prediction accuracy in Section 3.3, checks for robustness in Section 3.4, and studies the additional information content of futures in Section 3.5.

\subsection{Cox Proportional Hazard Model}

The empirical analysis is conducted in the Cox proportional hazard model setting (Cox, 1972) to investigate the factors that may affect the probability of default. The advantages of the Cox model include that it can handle right censoring and take time from origination to default into consideration. Also the Cox model is a semi-parametric technique that does not require choosing a specific probability distribution of the survival time, and is considered a more robust approach.

The model specification is as in (1), where $h(t)$ is the hazard function of default and $\lambda_{0}(t)$ is called the baseline hazard function. The hazard function represents the conditional probability that a borrower remains current on mortgage payment at $t+1$ given that the borrower has current status at time $t$. Estimation uses a partial likelihood method that allows estimation of only the $\beta$ coefficients without having to specify the baseline hazard function $\lambda_{0}(t)$. The event of interest is default, with prepayment as the competing risk. The explanatory variables in $X$ include both static variables which are obtained 
at origination and time-varying variables which are updated quarterly. The time-varying variables updated at each time $t$ include expectations, CLTV, loan age, interest rate difference, and lagged unemployment rate.

$$
h(t, X)=\lambda_{0}(t) \exp (X \beta)
$$

\subsection{Housing Expectations and Default}

In making the decision to default, borrowers weigh the benefit of keeping the house versus the cost of making the mortgage payments. Expected house prices play a central role in the valuation process. On the one side, the value of house to the borrower includes the expected future house price. On the other side, as Kau and Kim (1994) and Kau et al. (1994) noted, the cost of the mortgage payments to the borrower needs to take into consideration the value of the future default option. This future default option value is affected by the expected future house price. Foote et al. (2008) used a two time period

model to illustrate that higher expectations of future house prices reduce the incentive to default even in face of current negative equity since borrowers are in hope of market recovery in the future, which may bring them to positive equity.

Despite of the importance of housing expectations, the existing proxies are mainly model based and backward-looking in nature. In a normal housing market when housing prices are relatively predictable, these measures might work well. However, in the recent housing market, those model based measures performed poorly in forecasting housing price movements (Goetzmann et al., 2009). Also, since model based measures rely solely on past price information, the same variable such as past year appreciation may represent both the past market condition and expectation, which makes it difficult to disentangle the two effects.

In addition, an identification issue can arise when using both the past appreciation rate and the HPI updated current loan-to-value ratio in the Cox proportional model since the past appreciation and the HPI updated CLTV ratio could be highly correlated. However, the correlation between these two variables is 0.0686 for this sample so that identification is not a serious problem.

We first compare the regression results with different proxies of housing expectations. Table 4 reports the coefficient estimates, with the state 
clustered standard error in parenthesis. The first regression has expectations inferred from transaction prices of futures. The second uses the past year appreciation of CSI. The third one uses the past year appreciation from FHFA and the last one uses the one-year time series forecasts of housing appreciation from the ARIMA models.

The results show that futures behave differently from other proxies. First, from the model fit perspective, futures yield the highest model fit as measured by the minimum value of $-2 \ln L$ among four different proxies. This indicates that futures might capture the true expectations better than other proxies. Second, coefficients of futures and time series have negative signs which suggest that higher housing expectations lower the probability of default, while both measures of past appreciation have positive signs. Futures also have the largest magnitude estimates. Third, as for statistical significance, only futures are significant at the one percent significance level. In sum, futures are the only measure that shows that higher housing expectations significantly reduce the default propensity as predicted by theory. The overall results suggest that different proxies could lead to quite different inferences concerning the role of housing expectations. Although inaccurate proxies may indicate that housing expectations do not play an important role in default decisions, futures seem to conform more closely to our prior beliefs.

From the futures estimates in Table 4, a one percent increase in housing expectation decreases the hazard of default by 1.32 percent $(\exp (-0.0133 \cdot 1)-$ $1=-1.32 \%)$. An expected one percent decrease in housing expectation increases the hazard of default by 1.34 percent $(\exp (-0.0133 \cdot-1)-1=$ $1.34 \%$ ). Although negative equity is a necessary condition for strategic default, expectations of house price declines may lead homeowners at the margin to make a decision to default.

Other variables have the expected signs. A larger current loan-to-value ratio, having a second lien, and a higher contract rate lead to a higher propensity to default. Higher Fico scores and full documentation decrease the propensity to default. Various exotic loans increase the propensity to default relative to the fully amortized fixed rate mortgages. Seasoned loans have a lower probability of default. Macroeconomic conditions such as the lagged unemployment also affect loan performance. Neighborhoods with higher incomes have lower default rates. 


\subsection{Out of Sample Prediction Accuracy}

To further investigate the out of sample model prediction accuracy for different expectation measures, we perform two experiments in this section. The first out of sample experiment is using the origination year 2006 cohort for estimation and using the origination year 2007 cohort for prediction analysis. The second experiment is using the pre-2009 data for estimation and using the 2009 data for prediction analysis.

After fitting the estimation sample, we calculate the survival probabilities for each observation in the prediction sample based on estimates from the fitted model. ${ }^{10}$ The survival probability is the predicted probability of surviving to time $t+1$ given survival to time $t$. One subtracted by the survival probability gives the predicted default probability, that is the probability of defaulting at time $t+1$ given current status at time $t$.

The predicted default probability is a continuous variable, while the observed mortgage status is a discrete variable. Prediction errors for a binary variable fall into two categories. First, one could predict current status when the true status is default. This could lead to rejecting a "valid" loan modification which could have changed the status to current (with modification) from default (without modification). This is analogous to a type I error in statistics where one rejects a true null hypothesis. Second, one could predict default when the true status is current which may lead to granting a loan modification to a borrower who would have continued to stay current. This is analogous to a type II error in statistics where one accepts a false null hypothesis of default. Prediction errors also affect valuation of mortgage backed securities and the risk management of portfolios with mortgage related assets.

By adopting a decision rule of $\operatorname{Pr}($ default $) \geq c \rightarrow$ decision, where $c$ is a cutpoint value between 0 and 1, there is a tradeoff between type I and type II errors. A low value of $c$ would result in low levels of type I errors but would lead to high levels of type II errors, and vice versa.

Since setting $c$ leads to varying rates of type I and type II errors, this makes it hard to compare model performances. A common approach to evaluate binary dependent variable model predictive accuracy when the cutpoint $c$ varies is to compare the area under the receiver operating (ROC) curve (Zhou et al., 2002). The area under the ROC curve is termed the AUC

\footnotetext{
${ }^{10}$ In order to calculate the survival probability, we also estimate the baseline hazard function after estimating the coefficient $\beta$.
} 
statistic. The ROC is a plot of false positive rate (x-axis) versus true positive rate (y-axis) for the full spectrum of possible cutpoints $c$ ranging from 0 to 1. The AUC represents the probability that a randomly chosen default loan is correctly ranked higher than a randomly chosen non-default loan (Hanley and McNeil, 1982). Higher AUC values indicate better model classification ability and better prediction accuracy.

Table 5 reports the AUC for the out of sample predictions for the four measures. Futures slightly outperform the other proxies for both experiments. For example, the forward prediction experiment yields the AUC of 0.7231 for futures, which is higher than that of past CSI (0.7101), past FHFA (0.7081), and time series forecasts (0.7207). These results indicate that using futures in the mortgage default model could improve the out of sample predictive power of the model.

\subsection{Robustness Checks}

Next we conduct various robustness checks by including year and/or state dummies to capture temporal and/or state fixed effects. Other variables and model specifications are the same as in Table 4. Table 6 reports the regression results. For simplicity, we only report the estimates of housing expectations. Panel A regressions include only annual dichotomous variables. Panel B regressions include only the state dichotomous variables and Panel $\mathrm{C}$ regressions include both state and year dichotomous variables. Across different specifications, futures consistently have a better model fit and the coefficients are significant and negative. Past CSI and past FHFA have mixed signs and remain insignificant. When year dummies are included, time series forecasts become significantly negative, but turn insignificant as state dummies are added in the regression.

\subsection{Information Content in Futures}

In this section, we investigate the information content of futures. In Table 7, except for expectations variables, we use the same model specifications as the regressions in Table 4. For the expectations variables, each regression includes futures and some other proxies to study whether futures contain information beyond past housing appreciation data. The results show that both coefficients and standard error estimates of futures are stable across various specifications. The coefficients are negative and significant even after 
controlling for various combinations of past price information. This indicates that futures contain information that are not reflected in the past housing prices, which is not surprising since individuals use all the available information to form their expectations, not just past prices.

\section{Conclusion}

Housing price expectations play a role in borrower mortgage default decisions. However, because of the difficulty of obtaining a good proxy, prior mortgage research either does not include housing expectation proxies in empirical work or uses a past price based approach.

This paper proposes to use information from housing futures contracts as an alternative proxy since the transaction prices incorporate expectations for future house prices. As an example, we compare the performances of four different proxies for expectations in explaining borrower mortgage default behavior. The results show that the futures based proxy outperforms other proxies by having the highest regression model fit as well as being the only proxy that shows a significant effect in the correct direction on mortgage default behavior. Futures also outperform other proxies in term of out of sample prediction accuracy. The results also show that futures contain additional information that is not contained in the past housing prices.

Since housing expectations may affect various real estate issues such as mortgage credit supply, housing demand and housing supply, the use of futures may help these other research areas. Finally, the newly launched RPX housing futures trading on CBOE Futures Exchange, which covers more cities, may increase the potential for using futures in real estate research.

The authors would like to thank the helpful comments from James Kau, Carlos Slawson, and other participants in LSU seminar, UGA seminar and AREUEA annual conference. We would like to thank the very helpful comments from one anonymous referee. We appreciate the support from Blackbox Logic, LSU High Performance Computing Center, and LSU Finance department. We thank Cihan Uzmanoglu for help with the data. All errors are our own. 


\section{References}

Ambrose, B. W., R. J. Buttimer Jr., and C. A. Capone (1997). Pricing mortgage default and foreclosure delay. Journal of Money, Credit and Banking 29(3), 314-325.

Bajari, P., C. S. Chu, and M. Park (2008). An empirical model of subprime mortgage default from 2000 to 2007. NBER working paper series.

Case, K. E., and R. J. Shiller (1989). The efficiency of the market for singlefamily homes. The American Economic Review 1, 125-137.

Case, K. E., R. J. Shiller, and A. N. Weiss (1993). Index-based futures and options markets in real estate. Journal of Portfolio Management 19(2), 83-92.

Cox, D. (1972). Regression models and life-tables. Journal of the Royal Statistical Society. Series B (34), 187-220.

Demyanyk, Y. and O. Van Hemert (2009). Understanding the subprime mortgage crisis. Review of Financial Studies. forthcoming.

Foote, C. L., K. Gerardi, and P. S. Willen (2008). Negative equity and foreclosure: Theory and evidence. Journal of Urban Economics 64(2), $234-245$.

Goetzmann, W. N., L. Peng, and J. Yen (2009). The subprime crisis and house price appreciation. Working paper, available at: http://ssrn.com/paper=1340577.

Grkaynak, R. S., B. P. Sack, and E. T. Swanson (2007). Market-based measures of monetary policy expectations. Journal of Business and Economic Statistics 25(2), 201-212.

Hanley, J. A., and B. J. McNeil (1982). The meaning and use of the area under a receiver operating ( ROC ) curve characteristic. Radiology 143, 29-36.

Kau, J. B., D. C. Keenan, and T. Kim (1994). Default probabilities for mortgages. Journal of Urban Economics 35 (3), 278-296. 
Kau, J. B. and T. Kim (1994). Waiting to default: The value of delay. Journal of the American Real Estate and Urban Economics Association 22(3), 539551.

Krueger, J. T. and K. N. Kuttner (1996). The fed funds futures rate as a predictor of federal reserve policy. Journal of Futures Markets 16(8), 865-879.

Leventis, A. (2008). Real estate futures prices as predictors of price trends. FHFA working paper.

Makridakis, S., S. Wheelwright, and V. McGee (1983). Forecasting: methods and applications. John Wiley, New York.

Shiller, R. J. (2007). Understanding recent trends in house prices and homeownership. in proceedings of the symposium "Housing, housing finance, and monetary policy." Kansas City: Federal Reserve Bank of Kansas City, $89-123$.

Zhou, X. H., D. K. McClish, and N. A. Obuchowski (2002). Statistical Methods in Diagnostic Medicine. John Wiley \& Sons, New York. 
Table 1: Variable Definitions

\begin{tabular}{|c|c|}
\hline Variable & Definition \\
\hline Default & First 90 days delinquency. \\
\hline Expectation & Proxies for housing appreciation expectation. \\
\hline Futures & $\begin{array}{l}\text { Housing expectation derived from housing } \\
\text { futures. }\end{array}$ \\
\hline Past CSI & Past year appreciation from CSI. \\
\hline Past FHFA & $\begin{array}{l}\text { Past year appreciation from FHFA housing } \\
\text { index. }\end{array}$ \\
\hline Time Series & $\begin{array}{l}\text { Time series forecast of next year housing ap- } \\
\text { preciation. }\end{array}$ \\
\hline CLTV & HPI updated current loan-to-value ratio. \\
\hline Piggyback & $\begin{array}{l}\text { Dummy variable, }=1 \text { if the property has ju- } \\
\text { nior liens at origination, }=0 \text { otherwise. }\end{array}$ \\
\hline Interest & Initial contract rate of the mortgage. \\
\hline Fico & $\begin{array}{l}\text { Fair, Isaac and Company credit score of the } \\
\text { borrower at origination, scaled by } 100 \text {. }\end{array}$ \\
\hline Full Doc & $\begin{array}{l}\text { Dummy variable, }=1 \text { if borrower offers full } \\
\text { documentation for loan application, =0 oth- } \\
\text { erwise. }\end{array}$ \\
\hline Exotic ARM & $\begin{array}{l}\text { Dummy variable, }=1 \text { if adjustable rate mort- } \\
\text { gage with deferred amortization provisions } \\
\text { including interest only, negative amortiza- } \\
\text { tion and/or balloon payment, }=0 \text { otherwise. }\end{array}$ \\
\hline Hybrid ARM & $\begin{array}{l}\text { Dummy variable, }=1 \text { if adjustable rate mort- } \\
\text { gage with fixed initial interest rate, no de- } \\
\text { ferred amortization provisions, }=0 \text { otherwise. }\end{array}$ \\
\hline Reg ARM & $\begin{array}{l}\text { Dummy variable, }=1 \text { if adjustable rate mort- } \\
\text { gage with no fixed initial interest rate, no } \\
\text { deferred amortization provisions, }=0 \text { other- } \\
\text { wise. }\end{array}$ \\
\hline Exotic FRM & $\begin{array}{l}\text { Dummy variable, }=1 \text { if fixed rate mortgage } \\
\text { with deferred amortization provisions includ- } \\
\text { ing interest only and/or balloon payment, =0 } \\
\text { otherwise. }\end{array}$ \\
\hline FRM & $\begin{array}{l}\text { Dummy variable, }=1 \text { if fully amortized fixed } \\
\text { rate mortgage, }=0 \text { otherwise. }\end{array}$ \\
\hline Investor & $\begin{array}{l}\text { Dummy variable, }=1 \text { if the purpose of the use } \\
\text { of the houseyas an investment, }=0 \text { otherwise. }\end{array}$ \\
\hline Purchase & $\begin{array}{l}\text { Dummy variable, }=1 \text { if new purchase, }=0 \\
\text { otherwise. }\end{array}$ \\
\hline Loan Amount & The original loan amount, scaled by 10000 . \\
\hline Loan Age & Loan age in year. \\
\hline Prepay Penalty & $\begin{array}{l}\text { Dummy variable, }=1 \text { if the loan has prepay- } \\
\text { ment penalty, }=0 \text { otherwise. }\end{array}$ \\
\hline
\end{tabular}


Table 2: Summary Statistics for Housing Expectation Prediction Error (in $\%)$

\begin{tabular}{|c|c|c|c|}
\hline & MAE & RMSE & $\operatorname{Max}$ \\
\hline $\mathrm{CBSA}=14460$ & & Boston & \\
\hline Futures & 3.5096 & $4.0021 \quad-6.8031$ & 5.1187 \\
\hline Past CSI & 3.4694 & $4.8480-12.5622$ & 4.3710 \\
\hline Past FHFA & 3.3441 & -8.7382 & 4.7331 \\
\hline Time Series & 4.4839 & $6.0839-18.3994$ & 6.6072 \\
\hline $\mathrm{CBSA}=16980$ & & Chicago & \\
\hline Futures & 6.2781 & $\begin{array}{ll}7.6536 & -6.4341\end{array}$ & 16.1615 \\
\hline Past CSI & 8.3354 & $9.2480-17.0678$ & 11.3075 \\
\hline Past FHFA & 8.4901 & $9.5593 \quad-7.9613$ & 16.5559 \\
\hline Time Series & 10.1504 & -41.4136 & 14.0367 \\
\hline $\mathrm{CBSA}=19740$ & & Denver & \\
\hline Futures & 4.0041 & $5.0985 \quad-9.8921$ & 4.6256 \\
\hline Past CSI & 3.4941 & -9.6221 & 4.6752 \\
\hline Past FHFA & 3.0362 & $3.4425 \quad-4.5165$ & 5.8672 \\
\hline Time Series & 4.0887 & $5.0773-13.7557$ & 10.0432 \\
\hline $\mathrm{CBSA}=29820$ & & Las Vegas & \\
\hline Futures & 16.1533 & $\begin{array}{ll}17.7078 & -0.8037\end{array}$ & 28.8965 \\
\hline Past CSI & 15.9296 & $17.7061-27.2618$ & 24.2718 \\
\hline Past FHFA & 17.3333 & $18.4959-20.1603$ & 27.0031 \\
\hline Time Series & 18.1639 & $20.2435 \quad-38.0747$ & 28.9701 \\
\hline $\mathrm{CBSA}=31100$ & & Los Angeles & \\
\hline Futures & 11.4815 & $13.2243 \quad-17.1213$ & 20.9443 \\
\hline Past CSI & 16.8538 & $\begin{array}{ll}18.5602 & -29.6379\end{array}$ & 21.4300 \\
\hline Past FHFA & 17.3861 & $18.6574-23.5411$ & 24.9940 \\
\hline Time Series & 17.9991 & $19.6259 \quad-39.9177$ & 23.0501 \\
\hline $\mathrm{CBSA}=33100$ & & Miami & \\
\hline Futures & 10.5809 & $12.6196 \quad 0.2158$ & 23.2321 \\
\hline Past CSI & 17.5363 & $19.0863-27.0390$ & 25.9994 \\
\hline Past FHFA & 22.3482 & $24.0952-25.3734$ & 35.1607 \\
\hline Time Series & 14.5974 & $18.6807 \quad-39.3754$ & 33.6565 \\
\hline $\mathrm{CBSA}=35620$ & & New York & \\
\hline Futures & 3.7003 & $4.8899-13.1914$ & 8.1654 \\
\hline Past CSI & 6.0124 & $6.7742-11.7984$ & 12.3544 \\
\hline Past FHFA & 6.9793 & $\begin{array}{ll}7.6926 & -6.1583\end{array}$ & 12.8273 \\
\hline Time Series & 5.9520 & $7.5304-21.7005$ & 10.4550 \\
\hline $\mathrm{CBSA}=41740$ & & San Diego & \\
\hline Futures & 10.7188 & $12.3521-16.9942$ & 19.9770 \\
\hline Past CSI & 14.7859 & $17.2142 \quad-32.8432$ & 17.4838 \\
\hline Past FHFA & 13.9238 & $15.0436-23.9575$ & 18.3137 \\
\hline Time Series & 17.2327 & $19.4695 \quad-40.1732$ & 21.0785 \\
\hline $\mathrm{CBSA}=41860$ & & San Francisco & \\
\hline Futures & 14.9090 & $16.9468 \quad-26.5580$ & 29.0233 \\
\hline Past CSI & 18.7101 & $22.6373 \quad-46.2595$ & 24.9317 \\
\hline Past FHFA & 17.1143 & $18.8624 \quad-27.3689$ & 28.9272 \\
\hline Time Series & 23.5628 & $27.5822 \quad-62.2342$ & 36.3986 \\
\hline
\end{tabular}


Table 3: Pearson Correlation Coefficients between Housing Expectations from Futures and other Proxies

\begin{tabular}{cccc} 
CBSA & Past CSI & Past FHFA & Time Series \\
\hline 14460 & -0.2946 & 0.0568 & -0.3945 \\
& $(0.0522)$ & $(0.7144)$ & $(0.0081)$ \\
16980 & 0.3189 & 0.2267 & 0.3061 \\
& $(0.0348)$ & $(0.1389)$ & $(0.0433)$ \\
19740 & 0.2142 & 0.2909 & -0.0256 \\
& $(0.1626)$ & $(0.0554)$ & $(0.8692)$ \\
29820 & -0.2170 & -0.1431 & -0.1058 \\
& $(0.1571)$ & $(0.3541)$ & $(0.4942)$ \\
31100 & 0.6279 & 0.5664 & 0.6907 \\
& $(0.0000)$ & $(0.0001)$ & $(0.0000)$ \\
33100 & 0.1331 & -0.1433 & 0.5612 \\
& $(0.3892)$ & $(0.3535)$ & $(0.0001)$ \\
35620 & 0.7036 & 0.6560 & 0.7080 \\
& $(0.0000)$ & $(0.0000)$ & $(0.0000)$ \\
41740 & 0.5169 & 0.4820 & 0.7094 \\
& $(0.0003)$ & $(0.0009)$ & $(0.0000)$ \\
41860 & -0.0323 & 0.0935 & 0.0203 \\
& $(0.8352)$ & $(0.5459)$ & $(0.8958)$ \\
47900 & 0.0599 & -0.0459 & -0.0234 \\
& $(0.6994)$ & $(0.7673)$ & $(0.8800)$ \\
\hline \hline
\end{tabular}

Notes: This table reports the Pearson correlation coefficients between futures and other housing expectation proxies. The number in the parenthesis under the correlation coefficients is the p-value for the null hypothesis that the correlation coefficient is not different from zero. 
Table 4: Different Proxies for Housing Expectations

\begin{tabular}{|c|c|c|c|c|}
\hline & Futures & Past CSI & Past FHFA & Time Series \\
\hline Expectation & $\begin{array}{c}-0.0133^{* *} \\
(0.0040)\end{array}$ & $\begin{array}{c}0.0020 \\
(0.0037)\end{array}$ & $\begin{array}{c}0.0076 \\
(0.0036)\end{array}$ & $\begin{array}{c}-0.0018 \\
(0.0012)\end{array}$ \\
\hline CLTV & $\begin{array}{c}0.0229^{* *} \\
(0.0018)\end{array}$ & $\begin{array}{c}0.0228^{* *} \\
(0.0020)\end{array}$ & $\begin{array}{c}0.0238^{* *} \\
(0.0015)\end{array}$ & $\begin{array}{c}0.0218^{* *} \\
(0.0022)\end{array}$ \\
\hline Piggyback & $\begin{array}{c}0.5780^{* *} \\
(0.0380)\end{array}$ & $\begin{array}{c}0.5771^{* *} \\
(0.0393)\end{array}$ & $\begin{array}{c}0.5759^{* *} \\
(0.0387)\end{array}$ & $\begin{array}{c}0.5778^{* *} \\
(0.0398)\end{array}$ \\
\hline Interest & $\begin{array}{c}0.0749^{* *} \\
(0.0079)\end{array}$ & $\begin{array}{c}0.0744^{* *} \\
(0.0075)\end{array}$ & $\begin{array}{c}0.0737^{* *} \\
(0.0073)\end{array}$ & $\begin{array}{c}0.0753^{* *} \\
(0.0080)\end{array}$ \\
\hline $\mathrm{FICO}$ & $\begin{array}{c}-0.7787^{* *} \\
(0.0406)\end{array}$ & $\begin{array}{c}-0.7741^{* *} \\
(0.0421)\end{array}$ & $\begin{array}{c}-0.7742^{* *} \\
(0.0426)\end{array}$ & $\begin{array}{c}-0.7765^{* *} \\
(0.0428)\end{array}$ \\
\hline Full Doc & $\begin{array}{c}-0.3856^{* *} \\
(0.0466)\end{array}$ & $\begin{array}{c}-0.3926^{* *} \\
(0.0505)\end{array}$ & $\begin{array}{c}-0.3976^{* *} \\
(0.0481)\end{array}$ & $\begin{array}{c}-0.3865^{* *} \\
(0.0475)\end{array}$ \\
\hline Exotic ARM & $\begin{array}{c}0.5439^{* *} \\
(0.0418)\end{array}$ & $\begin{array}{c}0.5464^{* *} \\
(0.0453)\end{array}$ & $\begin{array}{c}0.5372^{* *} \\
(0.0462)\end{array}$ & $\begin{array}{c}0.5499^{* *} \\
(0.0432)\end{array}$ \\
\hline Hybrid ARM & $\begin{array}{c}0.5855^{* *} \\
(0.0238)\end{array}$ & $\begin{array}{c}0.5803^{* *} \\
(0.0265)\end{array}$ & $\begin{array}{c}0.5680^{* *} \\
(0.0263)\end{array}$ & $\begin{array}{c}0.5876^{* *} \\
(0.0237)\end{array}$ \\
\hline Exotic FRM & $\begin{array}{c}0.2199^{* *} \\
(0.0490)\end{array}$ & $\begin{array}{c}0.2231^{* *} \\
(0.0495)\end{array}$ & $\begin{array}{l}0.2200^{* *} \\
(0.0500)\end{array}$ & $\begin{array}{c}0.2248^{* *} \\
(0.0486)\end{array}$ \\
\hline Reg ARM & $\begin{array}{c}0.3725^{* *} \\
(0.0652)\end{array}$ & $\begin{array}{c}0.3635^{* *} \\
(0.0627)\end{array}$ & $\begin{array}{c}0.3563^{* *} \\
(0.0668)\end{array}$ & $\begin{array}{c}0.3717^{* *} \\
(0.0643)\end{array}$ \\
\hline Investor & $\begin{array}{c}0.0851 \\
(0.0470)\end{array}$ & $\begin{array}{c}0.0778 \\
(0.0495)\end{array}$ & $\begin{array}{c}0.0818 \\
(0.0492)\end{array}$ & $\begin{array}{c}0.0741 \\
(0.0480)\end{array}$ \\
\hline Purchase & $\begin{array}{r}-0.0066 \\
(0.0189)\end{array}$ & $\begin{array}{c}-0.0054 \\
(0.0184)\end{array}$ & $\begin{array}{c}-0.0114 \\
(0.0151)\end{array}$ & $\begin{array}{c}0.0009 \\
(0.0204)\end{array}$ \\
\hline Loan Amount & $\begin{array}{c}0.0004 \\
(0.0056)\end{array}$ & $\begin{array}{c}0.0024 \\
(0.0030)\end{array}$ & $\begin{array}{c}0.0023 \\
(0.0031)\end{array}$ & $\begin{array}{c}0.0020 \\
(0.0038)\end{array}$ \\
\hline Loan Age & $\begin{array}{c}-0.4098^{* *} \\
(0.0246)\end{array}$ & $\begin{array}{c}-0.4272^{* *} \\
(0.0208)\end{array}$ & $\begin{array}{c}-0.4354^{* *} \\
(0.0202)\end{array}$ & $\begin{array}{c}-0.4339^{* *} \\
(0.0190)\end{array}$ \\
\hline Prepay Penalty & $\begin{array}{c}0.0215 \\
(0.0491)\end{array}$ & $\begin{array}{c}0.0370 \\
(0.0455)\end{array}$ & $\begin{array}{c}0.0454 \\
(0.0434)\end{array}$ & $\begin{array}{c}0.0270 \\
(0.0500)\end{array}$ \\
\hline Rate Diff & $\begin{array}{c}-0.1784^{* *} \\
(0.0589)\end{array}$ & $\begin{array}{c}-0.1799^{* *} \\
(0.0552)\end{array}$ & $\begin{array}{c}-0.1594^{* *} \\
(0.0588)\end{array}$ & $\begin{array}{c}-0.1891^{* *} \\
(0.0544)\end{array}$ \\
\hline Lag Unemployment & $\begin{array}{c}-0.1809^{* *} 17 \\
(0.0349)\end{array}$ & $\begin{array}{c}-0.1817^{* *} \\
(0.0385)\end{array}$ & $\begin{array}{c}-0.1777^{* *} \\
(0.0381)\end{array}$ & $\begin{array}{c}-0.1803^{* *} \\
(0.0392)\end{array}$ \\
\hline Income & $\begin{array}{c}-0.3858^{* *} \\
(0.0651)\end{array}$ & $\begin{array}{c}-0.4094^{* *} \\
(0.0676)\end{array}$ & $\begin{array}{c}-0.4186^{* *} \\
(0.0689)\end{array}$ & $\begin{array}{c}-0.4032^{* *} \\
(0.0664)\end{array}$ \\
\hline$-2 \ln \mathrm{L}$ & 1623539 & 1623892 & 1623747 & 1623826 \\
\hline
\end{tabular}


Table 5: Out of Sample Prediction Accuracy: Area under ROC Curve (1)

\begin{tabular}{lrr} 
& Origination Cohort Prediction & Forward Prediction \\
\hline Futures & 0.8030 & 0.7231 \\
Past CSI & 0.8014 & 0.7101 \\
Past FHFA & 0.8013 & 0.7081 \\
Time Series & 0.8022 & 0.7207 \\
\hline \hline
\end{tabular}

Notes: This table reports the area under the ROC curve (AUC) for comparison of the out of sample predictions. The first experiment is using the origination 2006 cohort for estimation and using origination 2007 cohort for out of sample prediction. The second experiment is using pre-2009 data for estimation and year 2009 data for out of sample prediction. The AUC is calculated for the out of sample predictions. 
Table 6: Robustness Checks

\begin{tabular}{|c|c|c|c|c|}
\hline & Futures & Past CSI & Past FHFA & Time Series \\
\hline Panel A & \multicolumn{4}{|c|}{ Year Dummies Included } \\
\hline Expectation & $\begin{array}{c}-0.0195^{* *} \\
(0.0050)\end{array}$ & $\begin{array}{c}-0.0013 \\
(0.0051)\end{array}$ & $\begin{array}{c}0.0049 \\
(0.0052)\end{array}$ & $\begin{array}{c}-0.0039^{* *} \\
(0.0014)\end{array}$ \\
\hline$-2 \ln \mathrm{L}$ & 1622616 & 1623286 & 1623216 & 1623076 \\
\hline Panel B & \multicolumn{4}{|c|}{ State Dummies Included } \\
\hline Expectation & $\begin{array}{c}-0.0072^{* *} \\
(0.0028)\end{array}$ & $\begin{array}{c}-0.0058 \\
(0.0036)\end{array}$ & $\begin{array}{r}-0.0035 \\
(0.0057)\end{array}$ & $\begin{array}{c}-0.0020 \\
(0.0015)\end{array}$ \\
\hline$-2 \ln L$ & 1621696 & 1621756 & 1621759 & 1621731 \\
\hline Panel C & \multicolumn{4}{|c|}{ Year and State Dummies Included } \\
\hline Expectation & $\begin{array}{c}-0.0121^{* *} \\
(0.0045)\end{array}$ & $\begin{array}{r}-0.0095 \\
(0.0067)\end{array}$ & $\begin{array}{r}-0.0129 \\
(0.0111)\end{array}$ & $\begin{array}{c}-0.0030 \\
(0.0014)\end{array}$ \\
\hline$-2 \ln L$ & 1619962 & 1620111 & 1619982 & 1620095 \\
\hline \multicolumn{5}{|c|}{$\begin{array}{l}\text { Notes: This table reports the Cox proportional regression results of various robustness checks } \\
\text { by including year and/or state dummies to capture temporal and/or state fixed effects. Other } \\
\text { variables and model specifications are the same as in Table } 4 \text {. For simplicity, we only report } \\
\text { the estimates of housing expectations. Panel A regressions include only annual dichotomous } \\
\text { variables. Panel B regressions include only the state dichotomous variables and Panel C regres- } \\
\text { sions include both state and year dichotomous variables. The state clustered standard error is } \\
\text { in the parenthesis. }{ }^{* *} p<0.01\end{array}$} \\
\hline
\end{tabular}


Table 7: Combination of Forecasts in Regression

\begin{tabular}{lccccccc}
\hline & 1 & 2 & 3 & 4 & 5 & 6 & 7 \\
\hline Futures & $-0.0148^{* *}$ & $-0.0145^{* *}$ & $-0.0132^{* *}$ & $-0.0141^{* *}$ & $-0.0130^{* *}$ & $-0.0130^{* *}$ & $-0.0130^{* *}$ \\
& $(0.0041)$ & $(0.0038)$ & $(0.0045)$ & $(0.0034)$ & $(0.0046)$ & $(0.0040)$ & $(0.0041)$ \\
Past CSI & 0.0049 & & & -0.0025 & 0.0099 & & 0.0018 \\
& $(0.0029)$ & & & $(0.0063)$ & $(0.0077)$ & & $(0.0116)$ \\
\multirow{2}{*}{ Past FHFA } & & $0.0092^{* *}$ & & 0.0111 & & 0.0106 & 0.0096 \\
& & $(0.0036)$ & & $(0.0066)$ & & $(0.0049)$ & $(0.0070)$ \\
Time Series & & & -0.0001 & & -0.0032 & -0.0017 & -0.0021 \\
& & & $(0.0015)$ & & $(0.0034)$ & $(0.0017)$ & $(0.0036)$ \\
-2lnL & 1623479 & \multirow{2}{*}{1623360} & 1623539 & 1623352 & 1623415 & 1623330 & 1623328 \\
\hline \hline
\end{tabular}

Notes: This table reports the Cox proportional regression results by including various combinations of expectation proxies. Other than the expectations, other variables and model specifications are the same as in Table 4. For simplicity, we only report the estimates of housing expectations. The state clustered standard error is in the parenthesis. ${ }^{* *} p<0.01$ 